\title{
Intermediate hosts of Protostrongylus pulmonalis (Frölich, 1802) and P. oryctolagi Baboš, 1955 under natural conditions in France
}

\author{
Célia Lesage ${ }^{1,2}$, Cécile Patrelle ${ }^{1}$, Sylvain Vrignaud ${ }^{3}$, Anouk Decors $^{2}$, Hubert Ferté ${ }^{1}$ and Damien Jouet ${ }^{\text {* }}$
}

\begin{abstract}
Background: Protostrongylus oryctolagi and P. pulmonalis are causative agents of pulmonary protostrongyliasis in Lagomorphs in France. These nematodes need usually one intermediate host for its life cycle, a terrestrial snail. However, some studies, mainly in experimental conditions, have identified the species of snails acting as intermediate hosts.

Methods: In total, 3315 terrestrial snails and 307 slugs were collected in the field in South-Eastern France and analyzed to detect the presence of parasites. Identification of nematode parasites and snails were performed according to morphological and molecular approaches (D2 domain of the 28S rDNA for parasites; 185 and ITS-1 rDNA, COI and 16S mtDNA for snails).
\end{abstract}

Results: Eighteen snails were found positive for Protostrongylids larvae. Haplotypes of the larvae corresponding to sequences of $P$. oryctolagi and $P$. pulmonalis were detected. Morphological identification of molluscs based on shell characters revealed 4 different morphotypes, and molecular results confirm the membership of these gastropods to the Hygromiidae and revealed 4 different species: Candidula gigaxii, 2 species of Cernuella sp. and Xeropicta derbentina. All infested snails were collected in wine cultures.

Conclusion: This study displays the first description of intermediate hosts of $P$. oryctolagi and the first report of $X$. derbentina as natural intermediate host of $P$. pulmonalis.

Keywords: Protostrongyliasis, Lagomorphs, Snails, Intermediate hosts, Molecular identification, Epidemiology

\section{Background}

The superfamily of Metastrongyloidea is composed of about 181 species divided into seven families, most of which uses gastropods (generally terrestrial) as intermediate hosts in their life-cycle for the infestation of definitive hosts $[1,2]$.

Since the discovery of the role of snails in the development of Muellerius capillaris by Hobmaier and Hobmaier in 1929 [3], several studies have been implemented in order to identify intermediate hosts and to describe the infestation pathways. Life cycle of Angiostrongylidae has been largely studied, because of its involvement in a human infestation [4-6]. The intermediate hosts of Protostrongylidae

\footnotetext{
*Correspondence: damien.jouet@univ-reims.fr

${ }^{1}$ EA 4688 (VECPAR), UFR de Pharmacie, Université de Reims

Champagne-Ardenne, 51 rue Cognacq-Jay, 51096 Reims, France

Full list of author information is available at the end of the article
}

of domestic ruminants, parasites involved in diseases affecting pulmonary tract of livestock and responsible for economic losses [7], have also been well studied [8-12]. In contrast, developments of Protostrongylidae of Lagomorphs have been studied only in USA $[13,14]$. Yet, pulmonary protostrongyliasis, disease caused by these nematodes, is frequently encountered and occasionally implicated in the cyclic decline of hare populations in Europe $[15,16]$.

Life-cycle of Protostrongylidae includes a pulmonary adult stage in the definitive host. After emission, the first-stage larvae rejoins the intermediate host, snail or slug, by active or passive penetration [8,9,17-24]. Unlike the trematodes, first-stage larvae of Protostrongylidae migrate to the muscle of foot where they grow to the third-stage larvae in 25 to 30 days, depending on the external temperature $[25,26]$. Several land snails and slugs 
have previously been identified as intermediate hosts of Protostrongylidae $[1,27,28]$. Using experimental approaches, the authors considered that very few species of snail and slugs are refractory to infection by Protostrongylidae. However there are susceptibility differences depending on species, age, density, activity period of gastropods and mobility of first-stage larvae [29-33]. Actually, young of large size snail species with a life of several years were more susceptible to infection than adults and reverse for little species with a life of one year [34,35]. In addition, a same snails' species can be implicated both in the life cycle of Protostrongylus parasiting hares, and in the cycle of other parasites. For example, the snail species Oxyloma elegans (Risso, 1826) can be infested by P. pulmonalis (parasite of Lagomorphs) and Muellerius capillaris (parasite of small ruminants) [28].

All larvae stages of species of the same genus and even of different genera may be morphologically indistinguishable. Indeed species identification using morphological features is only possible on male adult worms [1]. Hence, to obtain a diagnostic tool to differentiate firststage or third-stage larvae of Protostrongylidae, a molecular approach must be privileged. Among available molecular markers, several studies on nematode species investigating specific identifications used ribosomal DNA, essentially the internal transcribed spacers (ITS1 and 2), known for their inter-specific variability [36-40], and also D2 domain (part of 28S) [41].

Similarly, species identification of snails is not so trivial, when based essentially on morphological criteria. The morphological polymorphism, inter and intra-specific, is extremely important in terrestrial snails depending on many parameters such as age, season, environmental conditions and biochemical factors [42-47]. Recently, using of molecular tools, by studying domains such as internal transcribed spacer and 18S rDNA or the COI and $16 \mathrm{~S}$ $\mathrm{mDNA}$, have facilitated the recognition of snails at a specific level. The combination of the morphological and molecular approaches has helped with the identification of snails difficult to distinguish purely on morphological criteria or only characterizable by specialized malacologists [48-55].

In France, a recent study conducted on hares identified two species of pulmonary parasite adults: $P$. (protostrongylus) oryctolagi Baboš, 1955 and P. (pulmostrongylus) pulmonalis (Frölich, 1802) [41]. Concerning their life cycle, several intermediate hosts of $P$. pulmonalis were previously reported: Oxyloma elegans (Risso, 1826), Pupilla muscorum (Linnaeus, 1778), Vallonia tenuilabris (Braun, 1843) and Vertigo alpestris Alder, 1838 [1,28]. However, intermediate hosts of $P$. oryctolagi have never been studied neither in natural nor in experimental conditions.

The aim of our study is to investigate and identify the intermediate hosts of Protostrongylids in natural conditions, by a morphological and molecular approach of parasites and snails, to determine the intensity of infestation and the conditions necessary for the development of these parasites in order to better understand their life cycle and assess risk of contamination for hares' populations.

\section{Methods}

\section{Collection}

Living gastropods (snails and slugs) were collected from eight areas of 100 hectares in the South-eastern France (Figure 1). The sampled sites were selected according to high density of gastropods and hares according to results previously obtained [41], and located in two open environments known to be favorite habitats of hares: grazed grasslands and wine cultures. On each area, samples were realized on 15 circular points of $1 \mathrm{~m}^{2}$. For wine areas, points were located in center or at edge of culture. On each point, a raised wooden plank was disposed on one side, providing shelter for snails when it is warm and causes their gathering under it [56]. Collections were implemented monthly from September to November in 2012 and from March to November in 2013 (except in summer, when snails are inactive and buried). The day of the visit was chosen to be a rainy one or after a rainy one, between 7.00 a.m and 9.00 a.m.

\section{Parasite examination}

Gastropods collected under planks or on plot, were examined for lungworm larvae. All were stored in separate labeled plastic boxes with ventilation openings and refrigerated $\left(4^{\circ} \mathrm{C}\right)$ for a maximum of three weeks. Except for the operculated snails the gastropods were drowned in an airtight jar full of water to kill them and involved the output of the foot out of the snail shell. Foots were recovered and crushed between two heavy glass slides to spread the snail tissue for observation with a stereomicroscope [34,57].

Larvae were observed in some snails in the musculature of the foot. After pre-identification on simple morphological criteria (size, sheath, darkened cuticle) as described by Boev (1984) [1], some larvae were extracted out of muscle, which was easy after dissection or pressing between slide and cover slip. Then they were preserved in $90^{\circ}$ ethanol for molecular analysis (Table 1).

After rinsing larvae in distilled water, then drying in an oven at $37^{\circ} \mathrm{C}$, DNA extraction was performed with a Qiamp DNA mini kit (Qiagen, Hilden, Germany) according to the manufacturer's instructions. Sequencing of the D2 domain of the $28 \mathrm{~S}$ was used for the identification of nematodes as described previously $[41,58]$ (Table 2). PCR products were directly sequenced in both directions with the primers used for DNA amplification (Genoscreen, France). Sequence alignment was performed 


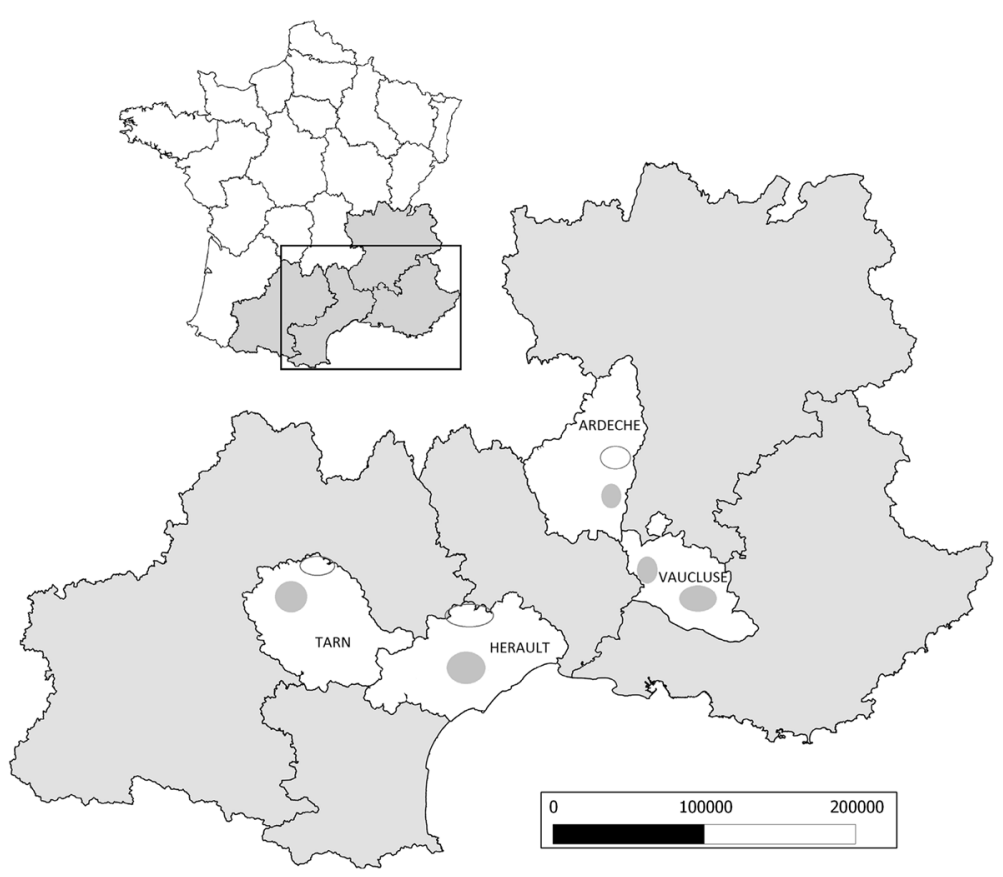

Figure 1 Map of study sites divided into four departments (Ardèche, Hérault, Vaucluse and Tarn) and composed two well represented habitats: open grassland (empty circle) or wine culture (gray full circle).

using the ClustalW routine included in the MEGA version 5 software and checked by eye.

Haplotypes of the larvae were compared to sequences of Protostrongylinae available in GenBank: P. pulmonalis (EU595590), P. pulmonalis (KJ450993-1018), P. oryctolagi (KJ450993-1018), P. boughtoni (EU595595), P. rushi (EU595598), P. stilesi (EU595599), P. rufescens (EU595600) and $P$. rupicaprae (EU595601).

\section{Gastropods identification}

Shells of positive and negative snails were preserved and primarily identified on morphological and morphometric features according to the collection of continental gastropods, available at the National Museum of Natural History of Paris [59]. In addition, for positive gastropods infested by nematode larvae, a part of foot was conserved in $90^{\circ}$ ethanol for molecular analysis (Table 1 ). DNA extraction of snail was performed using the same method as for nematode larvae. Sequencing of the ITS-1 and $18 \mathrm{~S}$ of rDNA and mitochondrial COI and $16 \mathrm{~S}$ were performed using primers and conditions described by Steinke et al. (2004) (Table 2) [60]. Polymerase chain reaction (PCR) was performed in a $50 \mu$ l volume using $5 \mu \mathrm{l}$ of DNA, and $50 \mathrm{pmol}$ of each of the primers. The PCR mix contained (final concentrations) $10 \mathrm{mM}$ Tris $\mathrm{HCl}$ (pH 8.3), $1.5 \mathrm{mM} \mathrm{MgCl}_{2}, 50 \mathrm{mM} \mathrm{KCl}, 0.01 \%$ Triton $\mathrm{X}$ 100, $200 \mu \mathrm{M}$ dNTP each base, and 1.25 units of Taq polymerase (Eppendorf, Germany). Our sequences were compared with sequences of terrestrial snails available in GenBank for all these domains. Our sequences were

Table 1 Isolates of larvae and snails from this study used for molecular analysis

\begin{tabular}{|c|c|c|c|c|c|c|c|c|c|}
\hline \multicolumn{8}{|l|}{ Snails } & \multicolumn{2}{|l|}{ Parasite } \\
\hline Ref. & Origin & $\begin{array}{l}\text { Morphological } \\
\text { identif. }\end{array}$ & Molecular identif. & $18 S$ & ITS-1 & COI & $16 S$ & Species & D2 \\
\hline EV1 & Vaucluse & \multirow{2}{*}{$\begin{array}{l}\text { Morphotype A } \\
\text { "white snails" }\end{array}$} & Xeropicta derbentina & KP335095 & KP335101 & KP335107 & KP335113 & Protostrongylus oryctolagi & KP335119 \\
\hline EV2 & Vaucluse & & Xeropicta derbentina & KP335096 & KP335102 & KP335108 & KP335114 & Protostrongylus pulmonalis & KP335120 \\
\hline ET3 & Tarn & \multirow{2}{*}{$\begin{array}{l}\text { Morphotype B } \\
\text { "Cernuella" }\end{array}$} & Cernuella sp. & KP335097 & KP335103 & KP335109 & KP335115 & Protostrongylus oryctolagi & KP335121 \\
\hline AT10 & Tarn & & Cernuella sp. & KP335098 & KP335104 & KP335110 & KP335116 & Protostrongylus oryctolagi & KP335122 \\
\hline EA1 & Ardèche & \multirow{2}{*}{$\begin{array}{l}\text { Morphotype C } \\
\text { "Candidula" }\end{array}$} & Candidula gigaxii & KP335099 & KP335105 & KP335111 & KP335117 & Protostrongylus oryctolagi & KP335123 \\
\hline ET1 & Tarn & & Candidula gigaxii & KP335100 & KP335106 & KP335112 & KP335118 & Protostrongylus oryctolagi & KP335124 \\
\hline AA550 & Ardèche & $\begin{array}{l}\text { Morphotype D } \\
\text { "Helicella" }\end{array}$ & nc & nc & nc & nc & nc & Protostrongylus oryctolagi & nc \\
\hline
\end{tabular}


Table 2 Primers and conditions used for molecular analyses of larvae and snails (according to Lesage et al., 2014 and Steinke et al., $2004[41,60])$

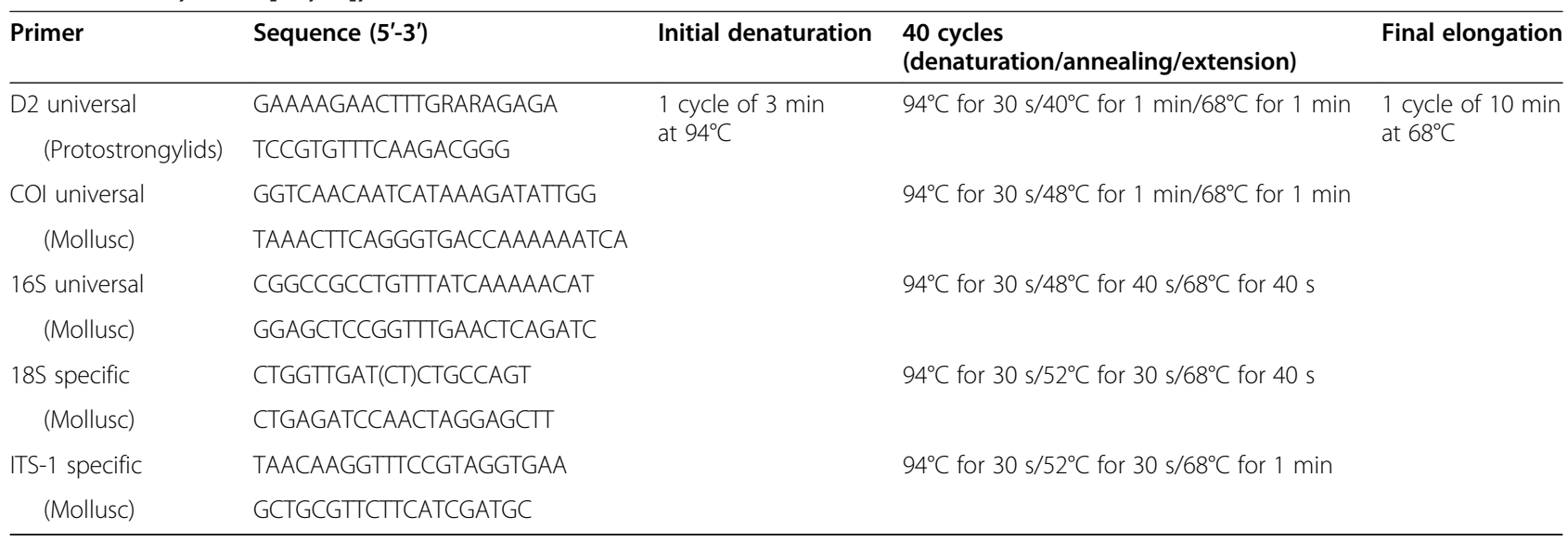

deposited in GenBank under accession numbers KP335095 to KP335124.

Phylogenetic trees were constructed using the Neighbor Joining (NJ), the Maximum Likelihood (ML), and Minimum Evolution (ME) methods using the MEGA 5 software [61]. For all NJ, ML, and ME analyses, the most appropriate nucleotide substitution model was determined, gaps were treated as missing data and internal node support was assessed by bootstrapping over 500 replicates.

\section{Results}

\section{Prevalence}

In total, 3622 gastropods were analysed, including 3315 terrestrial snails and 307 slugs. Gastropods were separated depending on their origin, grassland or wine crops. Morphological approach doesn't allow identifying snails at specific level but only at the family or sometimes at the generic level. They belong to two groups and eight families: Cyclophoridae (Prosobranchia) and, from Pulmonata, families of Chondinidae, Clausiliidae, Enidae, Helicidae, Hygromiidae, Vitrinidae and Zonitidae. Out of the 3315 snails, no Prosobranchia were positive for parasites. Eighteen Pulmonata were positive (0.54\%), all originated from wine cultures. A total of 123 third-stage larvae were observed and the number of larvae per snail varied from 1 to 52 with an average of 7 larvae.

Identification of slugs was evoked at family level [62,63]. Identification of slugs brings out four families: Agriolimacidae, Arionidae, Limacidae and Milacidae. None slug was positive for protostrongylids larvae.

\section{Identification of larvae}

Pre-identification of larvae of Protostrongylids was based on simple morphological criteria. The third stage (infective) larva of this group is generally covered by a double sheath. The upper sheath is thin, transparent, and the lower sheath is compact and rugose with rough traverse folds of brownish color. The larvae along with its sheath usually coil into a ring. (Figure 2) [1,12].

Larvae were then analyzed using molecular markers (D2) in order to identify them at the specific level. For seventeen positive snails, sequences of the larvae are $100 \%$ homologous with the haplotype of P. oryctolagi, whereas one snail was positive for larvae whose haplotype corresponds with P. pulmonalis deposited in GenBank.

\section{Identification of positive snails}

By pre-morphological identification based solely on shell, the 18 positive snails were all included in the Helicidae and Hygromiidae families, and separated into 4 groups corresponding to their morphotype: A) the first group of white snails including genera such as Xeropicta and Theba (8 snails); B) a group including snails with morphological features of the genus Cernuella (7 snails); C) a group including snails which morphotype corresponds with the genus Candidula (2 snails); D) the last group with one postive snail whose morphological criteria seems to correspond to the Helicella genus. Specimens of each group were found infected with $P$. oryctolagi larvae, except snails in group A in which the two species of parasites were found.

For each group, two snails were used for molecular analyses (A: sequences EV1 and EV2; B: seq. AT10 and ET3; C: seq. EA1 and ET1), except for the Helicella group where tests failed. We did not take into account this snail for our next results.

An initial study of the combined dataset of 18S, ITS-1, COI and $16 \mathrm{~S}$ sequences show the membership of all our positive snails to the Hygromiidae family (Figure 3) and the separation in three different clades corresponding to the different morphotypes. A second study, by analysing the specific $16 \mathrm{~S}$ and COI allows us to identify some of the species involved in the different groups (Figure 4). Groupe A is only composed of the species Xeropicta 


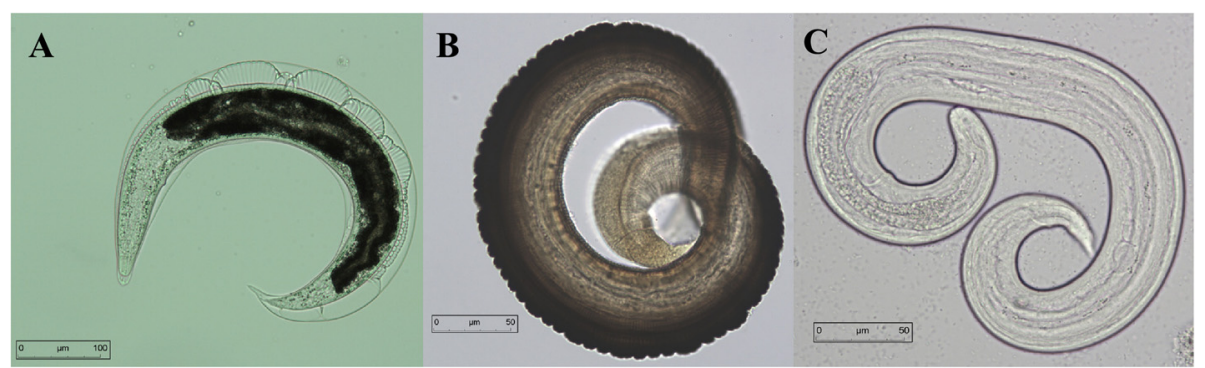

Figure 2 Different stages of infective larvae of Protostrongylus oryctolagi extracted from snail's muscle, with external and internal sheath (A), without external sheath (B) and without darkened cuticle (C).

derbentina Brusina, 1870 and group C of Candidula gigaxii (Pfeiffer, 1850). For group B molecular analyzes was not conclusive at specific level. Both haplotypes differ between groups. Estimation of the pairwise distances with other genera (70-75\% of homology) is in favor of their membership to the genus Cernuella, thus confirming the results obtained during the morphological identification. Among the Cernuella genus, the pairwise distances with other species do not separate specifically between the two haplotypes, with percentages of homology very close to several species such as Cernuella virgata, C. neglecta and C. Cisalpina, without consistency between the analyzed domain (16S or COI).

\section{Discussion}

Lungworm infections are frequently found in hares in France [41], but few studies have been conducted to look for intermediate hosts of these parasites in natural conditions. This approach is, however, essential for understanding the development of the parasite life cycle, and thus to evaluate the risk of dispersion and contamination of the parasite in populations of definitive hosts. Our study aims to find these hosts in natura for different species of protostrongylids previously isolated from lungs of hares in France, in order to identify the host-parasite relationship and more precisely the gastropod-nematode relationship, by using techniques previously tested for Trematodes [64-66].

Our research of potential intermediate hosts (Gastropods) was therefore carried out on the sites where positive hares had been located. It is important to note that the collection method used here is not suitable for small snail species approx a millimeter in size, living in ground litter and moving very little and very slowly, and already identified

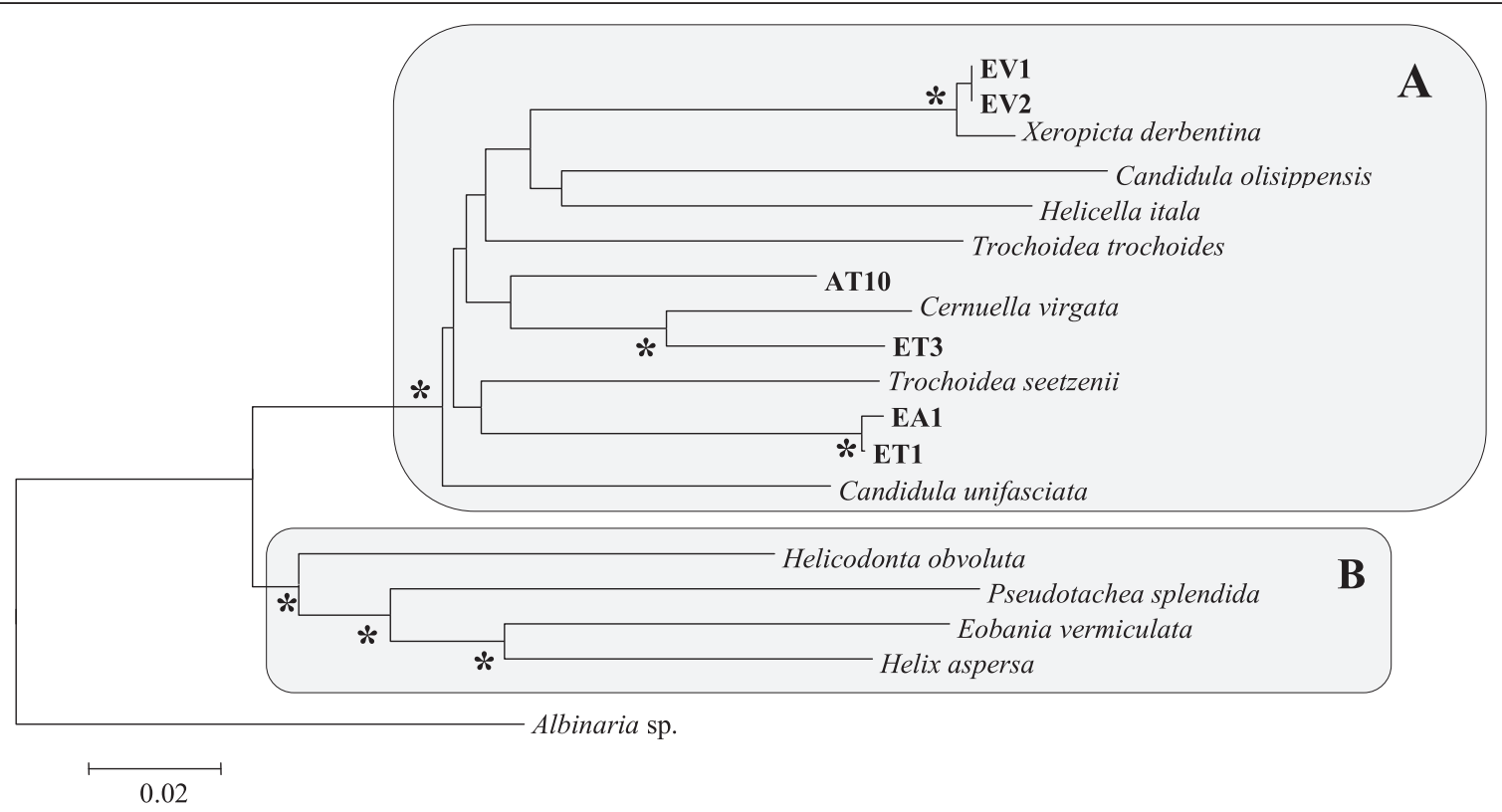

Figure 3 Phylogenetic tree based on a combined dataset of COI, 16S, $18 \mathrm{~S}$ and ITS-1 sequences with a total of 1677 nucleotide sites constructed using the Maximum Likelihood method and the general time reversible model $(G T R+I+\Gamma)$. The tree has been rooted using Albinaria sp. (AY546262/AY546342/AY546382/AY546302). The asterisk indicates bootstrap values of $>95$ for NJ, ML and ME. A = Hygromiidae; $\mathbf{B}=$ Helicidae. 


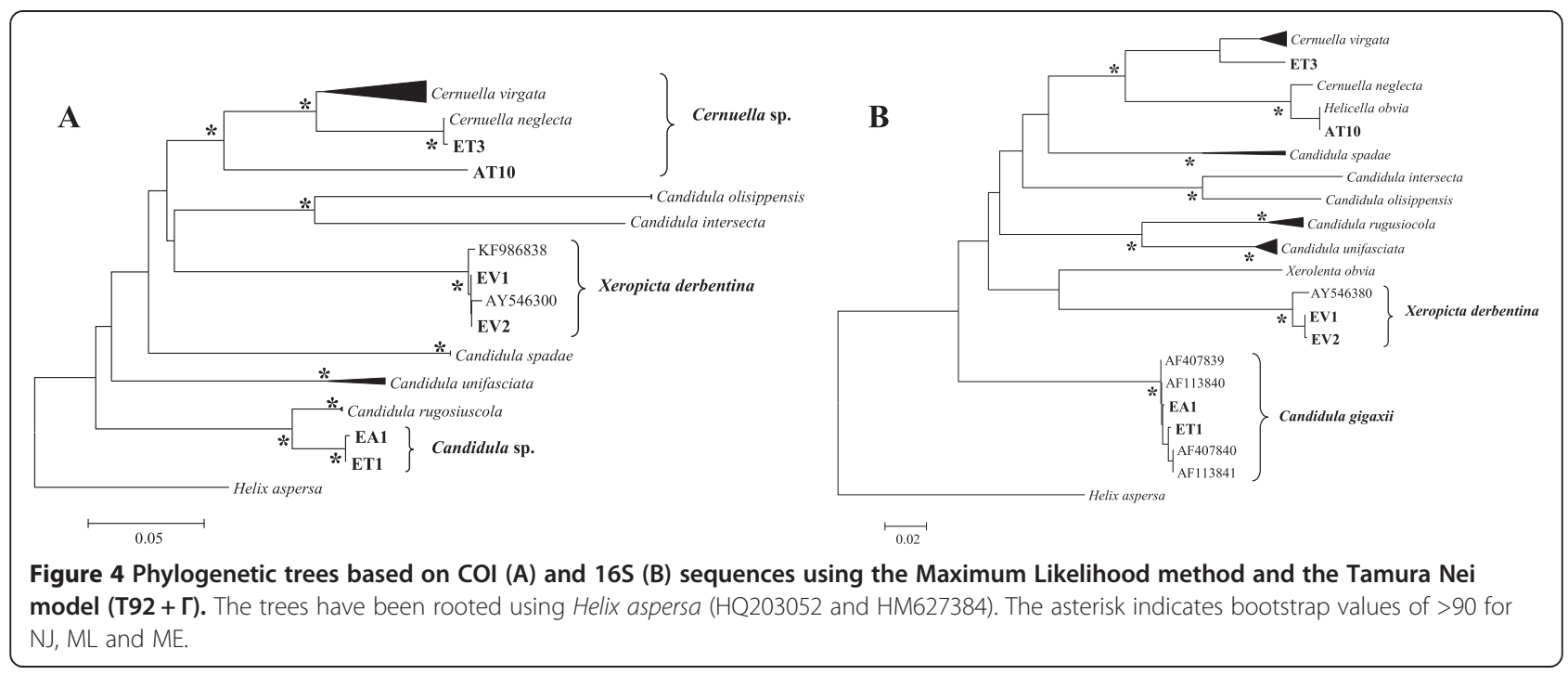

as an intermediate host of Protostrongylidae, e. g: Еuconulus fulvus or Vertigo alpestris [28]. Hence we cannot exclude the possibility that we missed some small snail species infested by Protostrongylids, meaning that the number of intermediate host species could be higher than five. Among the 3622 gastropods isolated, no slug was found positive after experimental infection, even if some specimens were previously reported as intermediate hosts. For terrestrial snails, eight different families were isolated, but only snails belonging to the Hygromiidae were found positive in natural conditions for Protostrongylids larvae. Other families of snails among the Pulmonata have been referenced in the literature, but always experimentally $[1,27,28]$. The method used to search for larvae in molluscs is different from that usually performed. If using pepsin-digestion is commonly done [67-70], especially for large molluscs, we prefer the pressing method of snails between two glass plates for small specimens. We do not compare these two methods here. The proportion of infested snails is low $(0.54 \%)$ but similar to other previous studies $[13,71,72]$. The number of larvae per snail varied from 1 to 52 with an average of 7 larvae per snail. The mortality rate is higher among the snails which harbour a considerable number of Neostrongylus linearis than the non-infected or moderately infected molluscs [73]. We can suppose that heavily infested individuals have not been collected during this study. Molecular analyzes of the larvae confirm the presence of two species of Protostrongylus, P. oryctolagi and P. pulmonalis, the same species as those previously found on hares in France.

The analysis of the positive snails based on the morphological criteria of the shell highlighted 4 groups, limited at the family or the genus level. Identification at the specific level is extremely difficult because of the important intra and inter-specific polymorphism. To be free from the constraints related to morphological identification, we used molecular tools, as previously described, to identify species incriminated as intermediate hosts $[54,55,60]$.

Larvae of $P$. pulmonalis was isolated from one individual belonging to the Xeropicta derbentina species. Larvae of $P$. oryctolagi were observed in four different species of snails: Candidula gigaxii (Pfeiffer, 1850), Xeropicta derbentina Brusina, 1870 and two Cernuella sp. If molecular results confirm the monophyly of the genus Cernuella, the haplotype Helicella obvia sensu Di Napoli et al. [54] most probably belong to the species Cernuella neglecta [74], we will not conclude at the specific level for both haplotypes isolated during our study. In fact, due to the high intra-specific morphological variability for this genus, sometimes including the internal features, identification is often very difficult. Under these conditions and based on the ambiguous molecular results, we consider these two haplotypes as Cernuella sp. pending a more comprehensive study.

This is the first report of all these snail species as natural intermediate host of Protostrongylus of Lagomorphs, except Xeropicta derbentina already infested experimentally by Protostrongylus tauricus [1].

Protostrongylidae are not highly specific in their use of intermediate hosts since many species of snail have been shown to be involved in its development $[32,75]$. The specificity between the nematode parasite and its intermediate host seem less strict compared to what can be observed especially for trematodes. However only some intermediate host species are probably important in natural transmission to the definitive host. Candidula gigaxii, Cernuella spp. and Xeropicta derbentina mainly colonize open fields with dry environment and calcareous soil typical of the landscape in the Mediterranean area $[63,76]$, with a large part of French territory and some European countries. Introduced from East of Europe in 1940, X. derbentina is limited in most open environments 
in Provence, mainly pasture fields and vineyards, where populations of snails are often very dense [77-79].

In our study, all larvae of Protostrongylus were isolated from snails collected in wine areas. All four species of intermediate hosts were also observed in grassland areas, but their abundance seems lower. It is possible that the wine crops are better adapted to the environment allowing snails to release larvae or offer optimal conditions for larvae survival. Third-stage larvae of Muellerius capillaris remain infective for at least six months at $-12^{\circ} \mathrm{C}$ [80], but are supposed to be very sensitive to dry conditions [81] and the wine areas, drier than grassland, do not seem best suited for larval survival. However, third-stage larvae, which are infective for the definitive host by ingestion, do not usually leave the foot when the snail is alive but their output is activated when it dies [75]. We can suggest that chemical treatments used in wine crops could modulate levels of parasitic infestation in snail populations. Indeed, Hock and Poulin [82] observed that pollutants can lead to increase cercariae excretion from aquatic snails.

An experimental study should be initiated to verify whether larvae excretion is facilitated by use of treatments, causing intense drooling and death by desiccation of snails.

\section{Conclusion}

Using a combined morphological and molecular approach for parasites and snails, this study displays the first report of natural intermediate hosts of $P$. oryctolagi and $P$. pulmonalis, two parasitic nematodes responsible for pulmonary protostrongyliasis in France, disease frequently encountered in hare populations in Europe. Understanding the life cycle of this kind of parasites is essential for risk factor identification. Among the two different habitats sampled, the wine crops seem favourable to the life cycle of hare Protostrongylus. In the future, it would be interesting to implement investigation in other environments in order to identify all habitats representing potential risks of disease for hare populations.

\section{Competing interests}

I confirm that I have read BioMed Central's guidance on competing interests and that none of the authors have any competing interests in the manuscript.

\section{Authors' contributions}

AD was responsible for SAGIR network and providing samples. SD realized the morphological identification of snails. CL, CP, HF and DJ analyzed the samples and molecular data and wrote the manuscript. All authors read and approved the final version of the manuscript.

\section{Acknowledgments}

Financial support was provided by ONCFS (Office National de la Chasse et de la Faune Sauvage: National hunting and wildlife agency). The authors would like to thank the members of the network SAGIR: The staff of hunters, hunting Federations, environmental officers of ONCFS and the local administrative Laboratories of veterinary analyses of Ardèche, Hérault, Tarn, Vaucluse and their General council, Fabrice Etienne, Cédric Arnal, Pascal Arnaud, Lise Guennegan, Guillaume Robert, Philippe Aubry, Clément Calenge and Philippe Geniez. We are grateful to Scott Harris for having kindly reviewed the English.

\section{Author details}

EA 4688 (VECPAR), UFR de Pharmacie, Université de Reims

Champagne-Ardenne, 51 rue Cognacq-Jay, 51096 Reims, France. ${ }^{2}$ Office National de la Chasse et de la Faune Sauvage, Direction des études et de la recherche, 5 rue de Saint Thibaud, 78610 Auffargis, France. ${ }^{3}$ USR 3278 CNRS-EPHE-Université Perpignan, Perpignan, France.

Received: 21 November 2014 Accepted: 5 February 2015

Published online: 15 February 2015

\section{References}

1. Boev SN. Protostrongylids, Fundamentals of Nematology. Helminthological Laboratory, Academy of Sciences of the USSR, Moscow. [English translation by the U.S Department of Agriculture, Washington, D.C., and Amerind Publishing Co., New Dehli, 1984, 338p.]; 1975.

2. Anderson RC. Nematodes parasites of vertebrates: their development and transmission. Wallingford: CAB International; 2000.

3. Hobmaier A, Hobmaier M. Die Entwicklung der Larve des Lungenwurmes Metastrongylus elongatus (Strongylus paradoxus) des Schweines und ihr Invasionsweg, sowie vorlaufige Mitteilung über die Entwicklung yon Choerostrongylus brevivaginatus. Münch tierärztl Woch. 1929;80:365.

4. Maurer RL, Graeff-Teixeira C, Thome JW, Chiaradia LA, Sugaya H, Yoshimura K. Natural infection of Deroceras laeve (Mollusca: gastropoda) with metastrongylid larvae in a transmission focus of abdominal angiostrongyliasis. Rev Inst Med Trop Sao Paulo. 2002;44:53-4.

5. Liu CY, Song HQ, Zhang RL, Chen MX, Xu MJ, Ai L, et al. Specific detection of Angiostrongylus cantonensis in the snail Achatina fulica using a loopmediated isothermal amplification (LAMP) assay. Mol Cell Probes. 2011;25:164-7

6. Kim JR, Hayes KA, Yeung NW, Cowie RH. Definitive, intermediate, paratenic and accidental hosts of Angiostrongylus cantonensis and its molluscan intermediate hosts in Hawaii. Hawaii J Med Public Health. 2013;72:10.

7. Stelfox J. Bighorn sheep in the Canadian Rockies. A history 1800-1970. Can Field Nat. 1971;85:101-22.

8. Samson J, Holmes JC. Modes of entry of first-stage larvae of Protostrongylus stilesi and P. rushi (Nematoda: Metastrongyloidea) in the snail intermediate host Vallonia pulchella. Can J Zool. 1985;63:2481-2.

9. Rezác P, Palkovic L, Holasová E, Busta J. Modes of entry of the first-stage larvae of Elaphostrongylus cervi (Nematoda: Protostrongylidae) into pulmonate snails Arianta arbustorum and Helix pomatia. Folia Parasitol. 1994;41:209-14.

10. Manga-Gonzalez MY, Morrondo-Pelayo P. Experimental infection by ovine Muellerius capillaris (Nematoda, Protostrongylidae) larvae of five species of molluscs (Hygrominae, Helicodontinae and Helicinae). Ann Parasit Hum Comp. 1999;1:30-41.

11. Jenkins EJ, Veitch AM, Kutz SJ, Hoberg EP, Polley L. Climate change and the epidemiology of protostrongylid nematodes in northern ecosystems: Parelaphostrongylus odocoilei and Protostrongylus stilesi in Dall's sheep (Ovis D. dalli). Parasitology. 2006;132:387-401.

12. Rogerson JD, Fairbanks WS, Cornicelli L. Ecology of gastropod and bighorn sheep hosts of lungworm on isolated, semiarid mountain ranges in Utah, USA. J Wildl Dis. 2008:44:28-44.

13. Kralka RA, Samuel WM. Emergence of larval Protostrongylus boughtoni (Nematoda: Metastrongyloidea) from a snail intermediate host, and subsequent infection in the domestic rabbit (Oryctolagus cuniculus). J Parasitol. 1984;70:457-8

14. Kralka RA, Samuel WM. The lungworm Protostrongylus boughtoni (Nematoda, Metastrongyloidea) in gastropod intermediate hosts and the snowshoe hare, Lepus americanus. Can J Zoo. 1990;68:2567-75.

15. Bull PC. Ecology of helminth parasites of the wild rabbit (Oryctolagus cuniculus) in New Zealand. Bull New Zealand Dept Sci and Indust Research. 1964;158:1-147.

16. Chroust K, Vodnansky M, Pikula J. Parasite load of European brown hares in Austria and the Czech Republic. Vet Med. 2012;57:551-8.

17. Hibler $\mathrm{CP}$, Lange RE, Metzger $\mathrm{CJ}$. Transplacental transmission of Protostrongylus spp. in bighorn sheep. J Wildl Dis. 1972;8:389.

18. Mozzer LR, Montresor LC, Vidigal THDA, Lima WS. Angiostrongylus vasorum: Experimental infection and larval development in Omalonyx matheroni. J Parasitol Res. 2011;2011:178748.

19. Kassai T. Larvae of protostrongylins in snails. Acta Vet Acad Sci Hung. 1958;8:223-36 
20. Svarc R. Ecological and pathological features in the bionomy of Cystocaulus ocreatus (Railliet et Henry, 1907) Mikacic, 1939 (the larval stage in the intermediate hosts). Biologia. 1977;32:575-84.

21. Skorping A. Lymnaea stagnalis as experimental intermediate host for the protostrongylid nematode Elaphostrongylus rangiferi. Z Parasitenkd. 1985;71:265-70.

22. Harris KR, Cheng TC. The encapsulation process in Biomphalaria glabrata experimentally infected with the metastrongylid Angiostrongylus cantonensis: light microscopy. Int J Parasitol. 1975;5:521-8.

23. Montresor LC, Vidigal THDA, Mendonça CLGF, Fernandes AA, de Souza KN, Carvalho OS, et al. Angiostrongylus costaricensis (Nematoda: Protostrongylidae): migration route in experimental infection of Omalonyx sp. (Gastropoda: Succineidae). Parasitol Res. 2008;103:1339-46.

24. Platt TR, Samuel WM. Mode of entry of first-stage larvae of Parelaphostrongylus odocoilei (Nematoda: Metastrongyloidea) into four species of terrestrial gastropods. Proc Helminthol Soc Wash. 1984;51:205-7.

25. Gibson DI, Jones A, Bray RA. Keys to Trematoda, Volume 1. Wallingford, UK and the Natural History Museum, London, UK: CAB International; 2002.

26. Samson J, Holmes J. The effect of temperature on rates of development of larval Protostrongylus spp. (Nematoda: Metastrongyloidea) from bighorn sheep, Ovis canadensis canadensis, in the snail Vallonia pulchella. Can J Zoo. 1984;63:1445-8.

27. Joyeux C, Gaud J. Recherches helminthologiques marocaines. Etudes sur la pneumonie vermineuse. Arch Inst Pasteur Maroc. 1946;3:383-461.

28. Grewal P, Grewal SK, Tan L, Adams B. Parasitism of molluscs by nematodes: types of associations and evolutionary trends. J Nematol. 2003;35:146-56.

29. Cabaret J. The polymorphism of shell ornementation fo three helicids and susceptibility to protostrongylid infection. J Moll Stud. 1983;12A:6-9.

30. Cabaret J, Diez-Banos P, Lopez-Sandez C, Morrondo-Pelayo P. Exposure of first-stage larvae of Muellerius capillaris (Nematoda) to dessication: smaller larvae and reduced infectivity in the land-snail host Candidula intersecta. Parasite J Soc Fr. 1997:4:307-10.

31. Diez-Baños P, Morrondo-Pelayo MP, Diez-Baños N, Cordero-Del-Campillo M, Núñez-Gutiérrez MC. The experimental receptivity of Helicella (Helicella) itala and Cepaea nemoralis (Mollusca, Helicidae) to larvae of Muellerius sp. and Neostrongylus linearis (Nematoda, Protostrongylidae) from chamois (Rupicapra rupicapra). Parasitol Res. 1989;75:488-94.

32. Georgiev D, Georgiev B, Matev I. Seasonal changes in morphology among populations of land snail Helicella obvia and effects of these changes on circulation of Protostrongylids in pastures of Stara Zagora, South Bulgaria. TJS. 2005:3:41-6.

33. Lahmar S, Cabaret J, Cheniti T. Land snails and periods at high risk for protostrongylid infection on a sheep-grazed pasture of northeast Tunisia. Vet Parasitol. 1990;36(1-2):105-15.

34. Solomon A, Paperna I, Alkon PU. The suitability of Trochoidea seetzenii of different ages as snail intermediate hosts of Muellerius cf. capillaris (Nematoda: Protostrongylidae). Int J Parasitol. 1996;26:1317-9.

35. Solomon A, llan P, Itamar G. Desiccation tolerance of Muellerius cf. capillaris (Nematoda: Protostrongylidae) first-stage larvae. J Parasitol. 1998;84:802-5.

36. Hoste H, Gasser RB, Chilton NB, Mallet S, Beveridge I. Lack of intraspecific variation in the second internal transcribed spacer (ITS-2) of Trichostrongylus colubriformis ribosomal DNA. Int J Parasitol. 1993;23:1069-71.

37. Gasser RB. Mutation scanning methods for the analysis of parasite genes. Int J Parasitol. 1997;27:1449-63.

38. Caldeira RL, Carvalho OS, Mendonça CL, Graeff-Teixeira C, Silva MC, Ben R, et al. Molecular differentiation of Angiostrongylus costaricensis, A. cantonensis, and $A$. vasorum by polymerase chain reaction-restriction fragment length polymorphism. Mem Inst Oswaldo Cruz. 2003;98:1039-43.

39. Chilton NB. The use of nuclear ribosomal DNA markers for the identification of bursate nematodes (order Strongylida) and for the diagnosis of infections. Anim Health Res Rev. 2004;5:173-87.

40. Chilton NB, Huby-Chilton F, Gasser RB, Beveridge I. The evolutionary origins of nematodes within the order Strongylida are related to predilection sites within hosts. Mol Phylogenet Evol. 2006;40:118-28.

41. Lesage C, Jouet D, Patrelle C, Guitton JS, Decors A, Ferté H. Protostrongylus pulmonalis (Frölich, 1802) and P. oryctolagi Baboš, 1955 (Nematoda: Protostrongylidae), parasites of the lungs of European hare (Lepus europaeus L.) in France: morphological and molecular approaches. Parasitol Res. 2014;113:2103-11.

42. Di Lellis MA, Sereda S, Geißler A, Picot A, Arnold P, Lang S, et al. Phenotypic diversity, population structure and stress protein-based capacitoring in populations of Xeropicta derbentina, a heat-tolerant land snail species. Cell Stress Chaperones. 2014;19(6):791-800.

43. Dieterich A, Fischbach U, Ludwig M, Di Lellis MA, Troschinski S, Gärtner U, et al. Daily and seasonal changes in heat exposure and the Hsp70 level of individuals from a field population of Xeropicta derbentina (Krynicki 1836) (Pulmonata, Hygromiidae) in Southern France. Cell Stress Chaperones. 2013;18(4):405-14.

44. Köhler HR, Lazzara R, Dittbrenner N, Capowiez Y, Mazzia C, Triebskorn R. Snail phenotypic variation and stress proteins: do different heat response strategies contribute to Waddington's widget in field populations? J Exp Zool B Mol Dev Evol. 2009;312(2):136-47.

45. Pfenninger $M$, Cordellier $M$, Streit B. Comparing the efficacy of morphologic and DNA-based taxonomy in the freshwater gastropod genus Radix (Basommatophora, Pulmonata). BMC Evol Biol. 2006;6:100.

46. Scheil AE, Hilsmann S, Triebskorn R, Köhler HR. Shell colouration and parasite tolerance in two helicoid snail species. J Invertebr Pathol. 2014;117:1-8.

47. Troschinski S, Di Lellis MA, Sereda S, Hauffe T, Wilke T, Triebskorn R, et al. Intraspecific variation in cellular and biochemical heat response strategies of Mediterranean Xeropicta derbentina [Pulmonata, Hygromiidae]. PLoS One. 2014;9(1):e86613.

48. Guiller A, Coutellec-Vreto MA, Madec L, Deunff J. Evolutionary history of the land snail Helix aspersa in the Western Mediterranean: preliminary results inferred from mitochondrial DNA sequences. Mol Ecol. 2001;10:81-7.

49. Pfenninger M, Magnin F. Phenotypic evolution and hidden speciation in Candidula unifasciata ssp. (Helicellinae, Gastropoda) inferred by 165 variation and quantitative shell traits. Mol Ecol. 2001;10:2541-54.

50. Wade CM, Mordan PB, Clarke B. A phylogeny of the land snails (Gastropoda: Pulmonata). Proc Biol Sci. 2001;268:413-22.

51. Tongkerd P, Lee T, Panha S, Burch JB, O' Foighil D. Molecular phylogeny of certain Thai gastrocoptine micro land snails (Stylommatophora; Pupillidae) inferred from mitochondrial and nuclear ribosomal DNA sequences. J Molluscan Stud. 2004;70:139-47.

52. Nekola JC, Coles BF, Bergthorsson U. Evolutionary pattern and process within the Vertigo gouldii (Mollusca: Pulmonata, Pupillidae) group of minute North American land snails. Mol Phylogenet Evol. 2009;53:1010-24.

53. White TR, Conrad MM, Tseng R, Balayan S, Golding R, de Frias Martins AM, et al. Ten new complete mitochondrial genomes of pulmonates (Mollusca: Gastropoda) and their impact on phylogenetic relationships. BMC Evol Biol. 2011;11:295

54. Dinapoli A, Zinssmeister C, Klussmann-Kolb A. New insights into the phylogeny of the Pyramidellidae (Gastropoda). J Mollus Stud. 2011;77(1):1-7.

55. Manganelli G, Salomone N, Giusti F. A molecular approach to the phylogenetic relationships of the western palaearctic Helicoidea (Gastropoda: Stylommatophora). Biol J Linn Soc Lond. 2005;85:501-12.

56. Cucherat $X$, Demuynck $S$. Les plans d'échantillonnage et les techniques de prélèvements des mollusques continentaux. MalaCo. 2008;5:244-53.

57. Cabaret J, Morand S. Single and dual infections of the land snail Helix aspersa with Muellerius capillaris and Alloionema appendiculatum (Nematoda). J Parasitol. 1990;76(4):579-80.

58. de Gouÿ Bellocq J, Ferté H, Depaquit J, Justine JL, Tillier A, Durette-Desset MC. Phylogeny of the Trichostrongylina (Nematoda) inferred from 285 rDNA sequences. Mol Phylogenet Evol. 2001;19:430-42.

59. Gargominy O, Ripken T. Une collection de référence pour la malacofaune terrestre de France. MalaCo. 2011;1:1-108.

60. Steinke D, Albrecht C, Pfenninger M. Molecular phylogeny and character evolution in the Western Palaearctic Helicidae s.l. (Gastropoda: Stylommatophora). Mol Phylogenet Evol. 2004;3:724-34.

61. Tamura K, Peterson D, Peterson N, Stecher G, Nei M, Kumar S. MEGA5 molecular evolutionary genetics analysis using maximum likelihood, evolutionary distance, and maximum parsimony methods. Mol Biol Evol. 2011;28:2731-9.

62. Germain L. Faune de France 21-22. Mollusques terrestres et fluviatiles. Paris: Fédération Française des Sociétés de Sciences Naturelles; (1930, 1931). (volume 21, 1930; volume 22, 1931), 897 pp. + 13 plates.

63. Kerney MP, Cameron RAD, Bertrand A. Guide des escargots et limaces d'Europe. , Lausanne and Paris: Delachaux \& Niestlé;1999. p. 370.

64. Ferté H, Depaquit J, Carré S, Villena I, Léger N. Presence of Trichobilharzia szidati in Lymnaea stagnalis and T. franki in Radix auricularia in northeastern France: molecular evidence. Parasitol Res. 2005;95:150-4.

65. Portier J, Jouet D, Vallée I, Ferté H. Detection of Planorbis planorbis and Anisus vortex as first intermediate hosts of Alaria alata (Goeze, 1792) in 
natural conditions in France: molecular evidence. Vet Parasitol. 2012;190:151-9.

66. Rondelaud D, Titi A, Vignoles P, Mekroud A, Dreyfuss G. Adaptation of Lymnaea fuscus and Radix balthica to Fasciola hepatica through the experimental infection of several successive snail generations. Parasit Vectors. 2014;7:296.

67. Cabaret J. Estimation of the infestation of mollusks by protostrongylids: parameters used and their interrelation. Ann Parasitol Hum Comp. 1982;57:367-74.

68. Nocture M, Cabaret J, Hugonnet-Chapelle L. Protostrongylid nematode infection of chamois (Rupicapra rupicapra) at the Bauges massif (French Alps). Vet Parasitol. 1998;77:153-61.

69. Gajadhar A, Steeves-Gurnsey T, Kendall J, Lankester M, Stéen M. Differentiation of dorsal-spined elaphostrongyline larvae by polymerase chain reaction amplification of ITS-2 of rDNA. J Wildl Dis. 2000;36:713-22

70. Qvarnstrom Y, Sullivan JJ, Bishop HS, Hollingsworth R, da Silva AJ. PCRbased detection of Angiostrongylus cantonensis in tissue and mucus secretions from molluscan hosts. Appl Environ Microbiol. 2007;73:1415-9.

71. Panin VY. Role of terrestrial mollusks in spreading elaphostrongylosis in deer. In Parasites of farm animals in Kazakhstan. Volume 3. Edited by Alma-Ata, Izdatel'stvo Akademii Nauk Kazakhstan SSR; 1964: 79-83.

72. Kralka R. Development and transmission of Protostrongylus boughtoni (Nematoda: Metastrongyloidea), a lungworm of the snowshoe hare (Lepus americanus). PhD thesis. University Of Alberta; 1983.

73. López C, Panadero R, Díez P, Morrondo P. Effect of the infection by Neostrongylus linearis on the survival of the intermediate host Cernuella (Cernuella) virgata. Parasite. 1998:5:181-4.

74. Groenenberg DS, Neubert E, Gittenberger E. Reappraisal of the "Molecular phylogeny of Western Palaearctic Helicidae s.l. (Gastropoda: Stylommatophora)": when poor science meets GenBank. Mol Phylogenet Evol. 2011;61(3):914-23.

75. Cabaret J. Réceptivité des mollusques terrestres de la région de Rabat à l'infestation par les protostrongles dans les conditions expérimentales et naturelles. PhD thesis. Museum D'histoire Naturelle; 1981.

76. Aubry S, Labaune C, Magnin F, Roche P, Kiss L. Active and passive dispersal of an invading land snail in Mediterranean France. J Anim Ecol. 2006;75(3):802-13.

77. Martin S. Caractérisation de l'anthropisation à l'Holocène en Provence et en Languedoc oriental, par les mollusques terrestres. PhD Thesis. Université Paris $1 ; 2004$.

78. Newel PF, Appleton TC. Aestivating snails - the physiology of water regulation in the mantle of the terrestrial pulmonate Otala lactea. Malacologia. 1979;18:575-58.

79. Cowie RH. Observations on the dispersal of two species of British land snail. J Conchol. 1980;30:201-8.

80. Sauerländer R. Cepaea nemoralis (Helicidae, Stylommatophora) as experimental intermediate host of Muellerius capillaris (Protostrongylidae, Nematoda). Z Parasitenkd. 1979:59:53-66.

81. Richards CS, Merritt JW. Studies on Angiostrongylus cantonensis in molluscan intermediate hosts. J Parasitol. 1967;53:382-8.

82. Hock SD, Poulin R. Exposure of the snail Potamopyrgus antipodarum to herbicide boosts output and survival of parasite infective stages. Int J Parasitol Parasites Wildl. 2012;15:13-8.

\section{Submit your next manuscript to BioMed Central and take full advantage of:}

- Convenient online submission

- Thorough peer review

- No space constraints or color figure charges

- Immediate publication on acceptance

- Inclusion in PubMed, CAS, Scopus and Google Scholar

- Research which is freely available for redistribution 